Olha Veryha ${ }^{1(A, B, C, D, E, F, G)}$

${ }^{1}$ Katolicki Uniwersytet Lubelski

The John Paul II Catholic University of Lublin

\begin{abstract}
Veryha, O. (2019). Znaczenie formacji modlitewnej we wspólnotach „Wiara i Światło"/The meaning of prayer formation in "Faith and Light” communities, Rozprawy Społeczne/Social Dissertations, 13(2), 1-15. https://doi.org/10.29316/rs/113307

Wkład autorów/ Authors' contribution:

A. Zaplanowanie badań/ Study design

B. Zebranie danych/ Data collection

C. Dane - analiza i statystyki/ Data a nalysis

D. Interpretacja danych/ Data interpretation

E. Przygotowanie artykułu/ Preparation of manuscript

F. Wyszukiwanie i analiza literatury/

Streszczenie

Głównym celem prezentowanej poniżej pracy jest znalezienie odpowiedzi na pytanie: Jakie znaczenie nadawane jest formacji modlitewnej we Wspólnotach „Wiara i Światło" przez opiekunów osób z niepełnosprawnością intelektualną? Ustaleniu odpowiedzi na pierwszą część tego problemu służyło studium literatury przedmiotu. W celu pozyskania odpowiedzi na drugą część przedstawionego zagadnienia, przeprowadzono badania ankietowe wśród opiekunów osób z niepełnosprawnością intelektualną we wspólnotach „Wiara i Światło”. W wyniku przeprowadzonych badań ankietowych został poznany pośrednio (poprzez pryzmat opinii opiekunów) obraz formacji modlitewnej i jej uwarunkowań we wspólnotach „Wiara i Światło”, a na tym tle zostało odczytane nadawane jej znaczenie. Na podstawie przeprowadzonych badań ustalono, że realizowana we Wspólnotach formacja modlitewna sprzyja rozwojowi moralnemu i duchowemu oraz kształtuje odpowiedni system wartości i postaw. Formacja modlitewna pomaga w realizacji podstawowej misji Wspólnoty, jaką jest akceptacja przez jej członków własnego życia, wzrastanie w wewnętrznej wolności oraz dzielenie się Dobrą Nowiną.
\end{abstract} Literature analysis

G. Zebranie funduszy/ Funds collection

\section{Tabele/Tables: 0}

Ryciny/Figures: 0

Literatura/References: 15

Otrzymano/Submitted: grudzień/December 2018

Zaakceptowano/Accepted: marzec/March 2019
Słowa kluczowe: Formacja modlitewna, Wspólnota „Wiara i Światło”, niepełnosprawni intelektualnie

\section{Summary}

The main goal of the below presented paper is to find the answer to the question: What is the meaning given to the prayer formation in the "Faith and Light" Communities by guardians of intellectually disabled people? Finding an answer to the first part of this issue was the purpose of the conducted study of subject literature. In order to get an answer for the second part of the presented matter, surveys were conducted among the guardians of people with intellectual disabilities in the communities of international association "Faith and Light". As a result of the conducted surveys, we were indirectly acquainted with the picture of prayer formation and its conditioning in "Faith and Light” communities and based on that the significance of it was interpreted. Based on the conducted study, it has been stated that the prayer formation realized in the Communities contributes to both moral and spiritual development and shapes the system of values and attitudes. Prayer formation helps in the implementation of the fundamental mission of the Community, which is every member's acceptance of their own lives, growing in inner freedom and sharing the Good News.

Key words: Prayer formation, Community, „Faith and Light”, intellectually disabled

Adres korespondencyjny: Olha Veryha, Katolicki Uniwersytet Lubelski im. Jana Pawła II, Al. Racławickie 14, 20-950 Lublin, e-mail: weryhaolga@student. kul.lublin.pl, tel.: 8144541 01. ORCID: https//orcid.org/0000-0003-2293-8713 Copyright by: Państwowa Szkoła Wyższa im. Papieża Jana Pawła II w Białej Podlaskiej, Olha Veryha

Czasopismo Open Access, wszystkie artykuły udostępniane są na mocy licencji Creative Commons Uznanie autorstwa-użycie niekomercyjne-na tych samych warunkach 4.0 Międzynarodowe (CC BY-NC-SA 4.0, http://creativecommons.org/licenses/by-nc-sa/4.0/). 


\section{Wprowadzenie}

Jednym z najważniejszych wyzwań wychowawczych dla rodzica lub opiekuna osoby z niepełnosprawnością intelektualną jest kształtowanie właściwych postaw moralnych i duchowych. Istniejący od lat 70-tych XX wieku „Ruch Wiara i Światło” oferuje należącym do niego osobom wsparcie $\mathrm{w}$ tym procesie. Szczególny sposób owego wsparcia stanowi modlitwa - wspólna oraz indywidualna. Celem niniejszego artykułu jest próba udzielenia odpowiedzi na pytanie o znaczenie formacji modlitewnej we Wspólnotach „Wiara i Światło”. Dla podejmowanej kwestii konieczne jest sprecyzowanie pojęcia „formacja modlitewna" i wyjaśnienie znaczenia formacji w rozwoju osoby ludzkiej, analiza społeczno-kulturowych uwarunkowań związanych z powstaniem ruchu „Wiara i Światło”, ze szczegółowym uwzględnieniem modlitwy jako elementu jego działalności, oraz prezentacja wyników własnych badań.

\section{Istota i znaczenie formacji modlitewnej w pro- cesie rozwoju osoby ludzkiej}

W powszechnym rozumieniu formacja (oznaczająca w języku łacińskim ukształtowanie, utworzenie - formatio), jest procesem trwałych oddziaływań na osobowość jednego człowieka przez inną osobę, instytucję lub grupę osób. Głównym jej celem jest kształtowanie osobowości, wyposażonej w dojrzałe struktury poznawczo-oceniające. Elementami formacji są: osoba (grupa osób) wywierająca wpływ, podmiot poddany oddziaływaniu i relacja oddziaływania. Relacja ta ma charakter obustronny - oznacza to, że podmiot - z założenia - poddany oddziaływaniu, jest aktywny, zarówno jak i podmiot inicjujący formację. Ta właściwość formacji sprawia, że jest ona „działaniem towarzyszącym i stymulującym samorozwój osoby, ułatwia samorealizację i dostarcza obiektywnych wzorców samooceny". Podstawowym warunkiem formacji jest respektowanie zasady podmiotowości w stosunku do osób, poddanych temu procesowi. Celem podstawowym - jest intensywny rozwój umysłowy i moralny, który odbywa się za zgodą i wiedzą osób w nim uczestniczących (Chlewiński, 1998, s.389).

Przedstawiciele chrześcijańskiej myśli pedagogicznej (np. J.G. Herbert) wskazują na bezpośredni, integralny związek pomiędzy formacją a wychowaniem. Rozumieją formację, jako „proces wywoływania człowieczeństwa", czyli przywracania i ochrony obrazu Boga, tkwiącego w duszy człowieka. Zakłada się, że w tym procesie bez pomocy autorytetu, człowiek nie jest w stanie zrozumieć sedna ludzkiej egzystencji (Nowak, 1999, s. 283-284). Wychowanie jest pomocnym narzędziem w osiągnięciu celu, jakim jest tak rozumiana formacja.

Warto tu zauważyć, że istnieje w literaturze przedmiotu kilka ujęć, pokazujących zależność między wychowaniem a formacją. Marian Nowak, analizując literaturę niemiecką i polską, wyróżnił cztery podstawowe stanowiska w tej kwestii. Pierwsze - postrzega

\section{Introduction}

One of the biggest challenges of child bringing up for a parent or a guardian of an intellectually disabled person is shaping the right moral and spiritual stances. Operating since the seventies of the 20th century "Faith and Light” offers its members support in this process. Prayer - group or individual - is a special kind of such support The goal of the following article is an attempt to answer the question about significance of prayer formation in „Faith and Light” Communities. For the undertaken issue, we have to specify the concept of „prayer formation” and explaining its importance in human development, and analyse socio-cultural conditions connected with the emergence of „Faith and Light", with special emphasis on prayer as an element of its activity a presenting the results of own studies.

\section{The essence and the significance of prayer formations in the human development process}

In the general understanding formation (that means shaping, forming in Latin - formation) is a process of persistent impact on one's personality by another person, institution or a group of people. The main goal of a formation is shaping of the personality, equipped in mature cognitive-critical structures. The elements of formation include: a person (a group of people) that has an influence, the subject of the influence and the relations of the interaction. This relationship is bilateral - it means that the subject - in principle - that is impacted is active, as well as the subject that initiates the formation. This feature of formation makes it " an action accompanying and stimulating selfdevelopment of a person, making self-realization easier and providing unbiased self-evaluation patterns". The primary condition of formation is respecting the rule of subjectivity in respect to the people, subjected to this process. The primary goal is an intense mental and moral development that takes place upon knowledge and consent of people participating in it (Chlewiński, 1998, p.389).

The representatives of Christian pedagogical conception (e.g. J.G. Herbert) point to a direct, integral relationship between formation and educating. They understand formation as „a process of evoking humanity", thus bringing back and protecting the image of God, embedded in human soul. It is assumed that without the help of a rolemodel, a human-being is not able to understand the essence of human existence (Nowak, 1999, pp. 283284). Bringing up is a helpful tool in achieving the goal of information, understood in such a way.

It is worth noting that in the literature there are few takes showing the correlation between bringing up and formation. When analysing German and Polish literature, Marian Nowak distinguished four primary stands in this matter. The first 
„formację” i „wychowanie” jako pojęcia bliskoznaczne, zamiennie używane. Drugie - traktuje formację jako cel, a wychowanie, jako złożony niekończący się proces, wspomagający jego realizację. Zwolennicy trzeciego stanowiska rozumieją formację jako jeden z elementów „wychowania”, które rozumiane jest bardziej globalnie, jako całokształt podejmowanych działań pedagogicznych. Naukowcy popierający czwarte stanowisko rozgraniczaja te pojęcia biorac pod uwage aspekty, których dotyczą. „Wychowanie”, ich zdaniem, odnosi się do aspektu moralnego i społecznego, a „formacja " - kulturalnego, intelektualnego i duchowego (Nowak, 1999). Potwierdzeniem takiego ujęcia są treści zawarte w Deklaracji o wychowaniu chrześcijańskim (2002), gdzie pojęciu „formacja” jest przypisywane konkretne zadanie - kształtowanie sfery duchowej („formacja duchowa”).

Przymiotnik „modlitewna” wskazuje na środek, za pomocą którego dokonuje się formacja osoby ludzkiej. Modlitwa jako pewien (niezwykle ważny) wyraz relacji czlowieka z Bogiem wymaga wysiłku i pracy nad jej rozwojem. Jak zaznacza Jan Paweł II, „człowiek nie przychodzi na świat ze znajomością modlitwy, trzeba się jej uczyć wciąż na nowo” (Jan Paweł II, 2001, nr 32). W szerokim ujęciu „modlitwa” jest definiowana jako personalne spotkanie z Bogiem o charakterze nadprzyrodzonej rozmowy z Nim. W chrześcijaństwie modlitwa jest „trynitarna” - skierowana do Boga Ojca przez Jezusa Chrystusa w Duchu Świętym. Modlitwa prywatna chrześcijanina może być bezpośrednio lub pośrednio kierowana do Boga i wiąże się z ofiarą Jezusa Chrystusa oraz własnymi ofiarami wiernych. Modlitwa może mieć różne formy: dziękczynienia, przebłagania, prośby lub uwielbienia. Forma i rodzaj (np. adoracja, rozmyślanie, kontemplacja) modlitwy są uwarunkowane wiarą, świadomością religijną, zdolnościami intelektualnymi i duchowymi oraz udzielonymi (przez Boga) łaskami (Kasjaniuk, 2008).

Modlitwa, jak podkreśla Jan Paweł II, jest spotkaniem i dialogiem miłości człowieka z Jezusem Chrystusem. Przybiera ona zróżnicowane formy wyrazu: błagania, dziękczynienia, uwielbienia, adoracji, kontemplacji, słuchania. Papież stwierdza, iż „modlitwa [...] może doprowadzić do tego, że człowiek zostanie całkowicie owładnięty przez Boskiego Umiłowanego, że będzie wrażliwy na wszelkie poruszenia Ducha i z dziecięcą ufnością zawierzy się sercu Ojca"( Jan Paweł II, 2001, nr 33). Taka modlitwa pomaga dążyć do celu ostatecznego, jakim jest życie wieczne we wspólnocie z Bogiem.

Katechizm Kościoła Katolickiego podkreśla ważność kształtowania osobowości przez modlitwę we wspólnotach (w tym religijnych): „, [wspólnota] jest jednym ze znaków i jednym z bodźców odnowy modlitwy w Kościele, pod warunkiem, że czerpie z autentycznych źródeł modlitwy chrześcijańskiej"[2689].

Mając na uwadze przedstawione wyżej ustalenia różnych autorów i wykorzystując przesłanki z nich płynące, można sformułować definicję formacji one - he sees „formation” and „bringing up” as synonymous terms, used interchangeably. The second one- treats formation as a goal and bringing up as a complex, never ending process, supporting realization of formation. The supporters of the third stand understand formation as one of the elements of „upbringing”, that is understood more globally, as a collection of all undertaken pedagogical actions. Scientists supporting the fourth stand distinguish between these aspects, taking into consideration the aspects that the concern. In their opinion Upbringing" relates to the moral and social aspect and „formation” to the cultural, intellectual and spiritual ones (Nowak, 1999). A confirmation of such take is the substance contained in Deklaracja o wychowaniu chrześcijańskim (Decree on Christian Education) (2002), where the term "formation” is ascribed a particular task - shaping the spiritual sphere („,spiritual formation").

The adjective "prayerful" indicates a measure by means of which the formation of a human being takes action. A prayer as a type of (very important) expression of a relationship between a human being and God requires effort and work on its development. Pope John Paul II stressed that , a human being does not come to the world with the knowledge of prayer, you constantly have to learn it over and over again" (John Paul II, 2001, no 32). In a broad perspective, „prayer" is defined as a personal meeting with God in a form of a supernatural conversation with him. In Christianity a prayer is „trinitarian” - it is directed at God the Father through Jesus Christ in the Holy Spirit. An individual prayer of a Christian can be directly or indirectly directed at God and is connected with the Jesus Christ's sacrifice and with personal sacrifices of the worshippers. A prayer can assume different forms: Thanksgiving Prayer, Imprecatory Prayer, Bidding Prayer or Worship Prayer. Forms and kinds (adoration, reflection, contemplation) of prayer are conditioned by faith, religious awareness, intellectual and spiritual abilities and mercy granted by God (Kasjaniuk, 2008). John Paul II stressed, that a prayer is a meeting and dialog of love between a person and Jesus Christ. It takes diversified forms of expression: begging, thanksgiving, worshiping, adoration, contemplation, listening. The Pope states that „prayer [...] can lead to being possessed by the Love of God, becoming sensitive to the actions of the Holy Spirit and with trust of a child one will entrust their heart to God". Such prayer can help to pursue an ultimate purpose that is the eternal life with God.

Catechism of the Catholic Church emphasizes the importance of shaping of personality through prayer in communities (including the religious ones): „[a community] is one of the signs and incentives of revival of prayer in Church, provided that it takes from the authentic sources of Christian prayer"[2689].

Considering different authors' arrangements shown above and using the premises stemming 
modlitewnej. Zatem: formacja modlitewna jest to proces kształtowania ludzkiej osoby, przez jej dobrowolny i aktywny udział w aktach modlitwy, mający na celu jej (osoby) wielokierunkowy rozwój, ze szczególnym akcentem na sferę duchową.

Takie działania mają za zadanie przybliżyć ludzką osobę do Boga za pomocą modlitwy, tym samym sprzyjając kształtowaniu bądź utrwaleniu określonej hierarchii wartości, postaw, stylu życia oraz pomagając $w$ integracji z innymi osobami, szukającymi relacji z Bogiem. Formacja modlitewna sprzyja również samorealizacji, która może odbywać się zarówno poprzez realizację $\mathrm{w}$ modlitwie indywidualnej, jak też zbiorowej (często jest to forma liturgii - mszy Świętej). Uzupełnieniem modlitwy w toku formacji modlitewnej, jak również jej swoistym podłożem, mogą być ofiary wiernych, pielgrzymowanie. Formacja modlitewna jest realizowana przede wszystkim w obrębie wspólnot religijnych, których celem jest przybliżenie się do pojmowania istoty Boga, budowanie osobowej relacji z Nim. Jednym z miejsc, w których jest - z założenia - realizowana formacja modlitewna, są wspólnoty „Wiara i Światło”.

\section{Społeczno-kulturowe uwarunkowania po- wstania Ruchu „Wiara i Światło”}

Historia powstania ruchu, obejmującego wspólnoty "Wiara i Światło”, jest związana z licznymi przeszkodami egzystencjalnymi, wątpliwościami z którymi zmagali się jej założyciele (Jean Vanier, Marie-Hélène Mathieu). U źródeł powstania ruchu „Wiara i Światło” leży specyficzna sytuacja społeczno-kulturowa we Francji w latach sześćdziesiątych minionego wieku. Specyfika jej zostanie tutaj ograniczona do opisu stosunku społeczeństwa (także, członków Kościoła) do osób z niepełnosprawnością intelektualną i oraz ich rodzin. Głównym przejawem relacji pomiędzy ogółem tego społeczeństwa a jego reprezentantami dotkniętymi niepełnosprawnością i ich bliskimi, było wykluczenie tej drugiej grupy przez społeczną większość ze sfery codziennego życia społecznego oraz ze sfery znaczących wydarzeń kulturowych (w tym również wydarzeń religijnych). Kiedy w latach 50-70-tych minionego wieku rodziły się we Francji (a także w innych krajach wysokorozwiniętych) dzieci z niepełnosprawnością intelektualną, lekarze zachęcali rodziców do pozostawiania takiego potomstwa w ośrodkach opiekuńczych lub placówkach szpitalnych. W przypadku rodzin niezamożnych takim miejscem ulokowania dziecka był na ogół specjalny oddział w szpitalu psychiatrycznym. Wiele dzieci z niepełnosprawnością intelektualną izolowano w szpitalach nawet w sytuacji, gdy nie potrzebowały one specjalistycznej opieki psychiatry (Mathieu, Vanier, 2014). Brak społecznej akceptacji dla osób „wychodzących poza normy” był odczuwalny nie tylko ze strony przeciętnych obywateli, ale nawet ze strony przedstawicieli Kościoła we Francji. Niewielki wybór prowadzonych przez Kościół ośrodków from them, we can formulate definitions of prayer formation, whereby: prayer formation is a process of shaping a person, by their voluntary and active participation in acts of praying, aiming at multidirectional development, with a special emphasis on the spiritual sphere.

Such activities are supposed to bring a person and God closer to one another through prayer, thereby contributing to shaping or perpetuating a certain hierarchy of values, attitudes, lifestyle and helping to integrate with another people, looking for a relationship with God. A prayer formation also fosters self-realization, that can take place through the realization in personal prayer as well as the group prayer (often in a form of liturgy - a Holy Mass). In a prayer formation, an addition to prayers, as well as a peculiar base, may be formed by sacrifices of worshippers, pilgrimage. A prayer formation is realized primarily within the religious communities, which goal is to get closer to understanding the nature of God, build a personal relationship with Him. One of the places where a prayer formation is realized in principle are „Faith and Light” communities.

\section{Socio-cultural determinants of creation of "Faith and Light" movement}

The history of establishment of the movement, including "Faith and Light” communities, is connected with numerous existential obstacles, doubts with which the founders (Jean Vanier, Marie-Hélène Mathieu) dealt with. At the very root of establishing „Faith and Light” movement lies a unique socio-cultural situation in France in the sixties of the last century. Its unique nature will only be limited here to describing the attitude of the society (including Church members) to intellectually disabled people and their families. The main sign of relations between the whole of the society and its representatives suffering from disability and their relatives was excluding the second group by the majority of the society from the sphere of everyday life and from the sphere of meaningful cultural events (including the religious ones). When in France (as well as in other high developed countries) in the $50 \mathrm{~s}-70$ s of the last century children with intellectual disability were born, doctors encouraged parents to leave such offspring in care centres and hospitals. In cases of families of modest means, such place of locating the child would usually be a special ward in a psychiatric hospital. Many intellectually disabled children were isolated in hospitals, when in fact they did not need a specialized psychiatric care (Mathieu, Vanier, 2014). Lack of social acceptance for people that were "outside the norms" was notable not only for average citizens, but even for the representatives of Church in France. A small choice of childcare facilities for intellectually disabled children led by Church and lack of qualified and specialized catechist caused negligence in supporting their spiritual development. Events in 
dla dzieci z niepełnosprawnością intelektualną oraz brak wykwalifikowanych katechetów specjalnych, powodowały zaniedbanie wsparcia ich rozwoju duchowego. Takie wydarzenia w życiu parafialnym, jak pielgrzymki czy codzienne oraz niedzielne nabożeństwa, nie były raczej dostępne dla osób z niepełnosprawnością intelektualną.

Camilla i Gérard Proffit - pomysłodawcy pielgrzymki, która zapoczątkowała powstanie „Ruchu Wiara i Światło" - również spotkali się z brakiem akceptacji społecznej dla swoich dwóch głęboko upośledzonych synów - Thaddée i Loic. Sami doświadczyli niezrozumienia ich pragnień, jeśli chodzi o plany, dotyczące ich udziału w wydarzeniach religijnych, np. w pielgrzymce do sanktuarium. Nie raz mówiono im: „Wasze dzieci nie zrozumiałyby niczego, co przeżywane jest w Lourdes. Poza tym istnieje ryzyko, że przeszkadzałyby innym pielgrzymom" (Mathieu, Vanier, 2014, s. 42-43). Ponieważ nie zostali przyjęci do żadnej z grup pielgrzymkowych ze względu na swoje niepełnosprawne dzieci, samodzielnie wyruszyli z nimi do Sanktuarium Maryjnego w Lourdes. W trakcie tego wyjazdu doświadczali wielokrotnie odrzucenia i braku szacunku - ze strony obsługi w hotelu, na ulicy, a także podczas kościelnych nabożeństw.

Historia rodziny Proffit zwróciła uwage innych przedstawicieli społeczeństwa, żywo zainteresowanych losem dotkniętych niepełnosprawnością i ich bliskich, na potrzebę „uzdrowienia serc, dzięki któremu będziemy mogli dostrzec niepowtarzalne piękno (...) osób [z niepełnosprawnością intelektualną - przyp. O.V.] i pomóc im odnaleźć swoje miejsce w Kościele i społeczeństwie" (Mathieu, Vanier, 2014, s. 68). W kręgu tych zainteresowanych znalazł się Jean Vanier, mający już doświadczenie pracy i wspólnej egzystencji z osobami z niepełnosprawnością intelektualną ${ }^{1}$. Wraz z podobnymi sobie entuzjastami Vanier postanawia zorganizować pierwszą pielgrzymkę rodzin $\mathrm{z}$ dziećmi dotkniętymi niepełnosprawnością do Lourdes. Przed rozpoczęciem pielgrzymki odbyły się liczne spotkania organizacyjne. Priorytetowym celem spotkań było dostosowanie części liturgicznej i animacyjnej do specyficznych potrzeb osób z niepełnosprawnością intelektualną, co umożliwiłoby „doświadczanie rzeczywistych chwil zjednoczenia z Bogiem w Jego Kościele” oraz byłoby „głębokim duchowym pokarmem dla rodziców i przyjaciół" (Mathieu, Vanier, 2014, s.70). Mimo trudności i dłuższych przygotowań, 9 kwietnia 1971 roku podczas pielgrzymki w Lourdes zebrało się 17 tysięcy ludzi z różnych części świata (w tym około 4 tys. osób z niepełnosprawnością intelektualną). Śpiewy, świadectwa, radosne przeżywanie czasu pielgrzymki, zostały opisane w prasie. Od tej pory Lourdes stało się miejscem przyjaznym dla dotychczas izolowanych społecznie osób z niepełnosprawnością inte-

\footnotetext{
${ }^{1}$ Jean Vanier jest za założycielem domów L’Arche (w Polsce znanych jako "Arki"). Zbudowane zostały w celu zgromadzenia osób z niepełnosprawnością oraz ich asystentów. Pierwsza Wspólnota powstała we Francji w 1964 roku. W Polsce pierwsza wspólnota L'Arche powstała w Warszawie w 1981 roku.
}

life of a parish such as pilgrimage or Sunday service were rather not accessible to intellectually disabled people.

Camilla and Gérard Proffit - the originators of the pilgrimage that initiated establishing of „Faith and Light Movement", dealt with the lack of social acceptance towards their two handicapped sons - Thaddée and Loic. They personally experienced misunderstanding of their needs, when it comes to plans regarding their participation in religious events e.g. pilgrimage to a sanctuary. They were told many times: "Your children would not understand anything that was experienced in Lourdes. Besides, there is a risk that they would bother other pilgrims"(Mathieu, Vanier, 2014, pp.42-43). Since they were not admitted to any of the pilgrimage groups due to their disabled children, they set off with them to the Marian Sanctuary in Lourdes. During this trip they experienced rejection and lack of respect from hotel workers, pedestrians on the streets and during services at church.

The case of Proffit family got attention of other representatives of the society who were interested in the fate of disabled and their relatives, for the need of „healing hearts that will enable us to see a unique beauty (...) of [intellectually disabled] people and help them find their place in the Church and in the society" (Mathieu, Vanier, 2014, p. 68). Jean Vanier who had experience in working and dealing with intellectually disabled people became a person of interest. ${ }^{1}$ Together with other enthusiasts he decides to organize the first pilgrimage of families with intellectually disabled children to Lourdes. Many organizational meetings took place before the pilgrimage started. The main priority of such meetings were adjusting liturgy and animation to special needs of intellectually disabled people, what would enable them „to experience the real moments of unification with God in His Church" and would be „a deep spiritual feast for their parents and friends" (Mathieu, Vanier, 2014, p.70). Despite difficulties and longer preparations, on the 9th of April 1971 during the pilgrimage to Lourdes, 17 thousand people from all around the world (including around 4 thousand people with intellectual disability) gathered together. Singing, testimonies and cheerful experiencing of the pilgrimage were described in the press. Since that time Lourdes has become a place friendly to people with intellectual disabilities that had until then been isolated. The pilgrimage to Lourdes started the establishing of „Faith and Light" communities that set as a goal to help people with disabilities and their families to find their own place in the Church and in the society. In response to a request from pilgrims: „We want „Faith and Light" to continue operating”, it was decided that the participants of the pilgrimage would continue meeting, that brought people with intellectual

Jean Vanier is a founder of L'Arche homes (in Poland they are known as "Arki"). They were built to gather people with disabilities and their assistants. The First Community was formed in France in 1964. The first L'Arche community in Poland was created in Warsaw in 1981. 
lektualną. Pielgrzymka do Lourdes zapoczątkowała powstanie wspólnot „Wiara i Światło”, które stawiały sobie za zadanie pomoc osobom z niepełnosprawnością i ich rodzinom w odnalezieniu własnego miejsca w Kościele i w społeczeństwie. W odpowiedzi na prośbę pielgrzymów: „Chcemy, żeby „Wiara i Światło" trwała nadal”, postanowiono aby uczestnicy pielgrzymki kontynuowali spotkania, skupiające osoby z niepełnosprawnością umysłową i fizyczną, ich rodziny i przyjaciół (Koczot, Kowalczyk, 2005, s. 3-6).

W Polsce pierwsze takie wspólnoty powstały we Wrocławiu i w Warszawie w 1978 r. Wspólnota wrocławska - utworzona z inicjatywy Teresy Brezy, mającej córkę z zespołem Downa. Breza była przekonana, że jej dziecku do rozwoju niezbędne jest coś więcej, niż zaspokojenie podstawowych potrzeb biologicznych i psychicznych, potrzebna jest formacja duchowa. Mając pewne informacje o „Wierze i Świetle”, udała się do Francji, by bliżej przyjrzeć się realiom działalności tego ruchu. Po spotkaniu z Marie-Hélène Mathieu postanowiła stworzyć wspólnotę „Wiara i Światło” w swoim mieście. Głównym celem tej i innych wspólnot było i jest stworzenie takich warunków, aby każda z osób z niepełnosprawnością wraz z rodziną czuła się przede wszystkim akceptowana przez innych, miała możliwość rozwoju swojego życia duchowego. Do celów szczegółowych „Wiary i Światła" należą: zapewnienie odpowiedniej formacji dla członków wspólnot, tworzenie więzi pomiędzy różnymi wspólnotami na poziomie międzynarodowym, wsparcie materialne biedniejszych wspólnot przez bogatsze, jednoczenie się wspólnot i ich członków w „[...]szerzej rozumianą wspólnotę w sensie ludzkim oraz chrześcijańskim, szczególnie zwracając uwagę na poszanowanie każdej kultury oraz wyznania”, nawiązanie współpracy z innymi stowarzyszeniami, w celu rozwoju moralnego i duchowego osób z niepełnosprawnością ( Statut Wiary i Światła,s.3).

Członkami „Ruchu Wiara i Światło” są: osoby z niepełnosprawnością, ich rodzice oraz Przyjaciele ${ }^{2}$ (osoby, które wyraziły chęć pogłębienia więzi z osobami z niepełnosprawnością oraz ich rodzicami, w tym kapelani). Cele i zasady funkcjonowania wspólnot „Wiara i Światło” zostały określone w dokumentach: Konstytucji, Karcie i Statucie. Konstytucja „Wiary i Światła” określa zasady organizacji i działania na poziomie lokalnym, prowincji i na szczeblu międzynarodowym. Karta „Wiary i Swiatła” w szczegółowy sposób opisuje zadania wspólnoty w wymiarze duchowym. Statut wyjaśnia cele działania i formalne warunki funkcjonowania we wspólnocie.

Każde spotkanie wspólnotowe jest podzielone na 3 „czasy”: 1) modlitwa, 2) świętowanie, 3) dzielenie się doświadczeniem i refleksjami. Czasem „czwartym” nazywane są spotkania osób niepełnosprawnych z przyjaciółmi w ich domach lub poza domami w celach integracyjnych, modlitewnych i rekreacyjnych.

2 Przyjaciel - określenie stosowane przez Jeana Vanier do opiekunów/ wolontariuszy osób z niepełnosprawnością, w celu podkreślenia wartości każdego człowieka i relacji towarzysko-partnerskich, zachodzących między uczestnikami Ruchu „Wiara i Światło” i w Domach „L’Arche" and physical disabilities, their families and friends together. (Koczot, Kowalczyk, 2005, p.3-6).

First communities in Poland of such kind were formed in Wrocław and Warsaw in 1978. The community in Wrocław - was formed on the initiative of Teresa Breza that has a daughter with Down syndrome. Breza was convinced that her child needed for her development something more than just satisfying her basic biological and psychical needs - a spiritual formation. Having gathered some information about „Faith and Light” she headed to France to take a closer look at the operating reality of this movement. After a meeting with Marie-Hélène Mathieu she decided to establish „Faith and Light” movement in her home city. The main goal of these communities and other ones as well was to create such conditions that every person with intellectual disability and their families would feel accepted and by others and have an opportunity for progress in their spiritual life. Detailed goals of „Faith and Light” consist of: providing a suitable formation for the members of communities, creating bonds between different communities at international level, financial support of poorer communities by the wealthier ones, uniting of the communities and their members into „[...] a community understood in a human and Christian sense, starting a cooperation with other associations in order to morally and spiritually develop disabled people (Statue of Faith and Light, p.3).

The members of „Faith and Light” movement comprise: people with disabilities, their parents and friends ${ }^{2}$ (people that agreed to deepen their bond with disabled people and their parents, including chaplains). The aims and operating procedures of „Faith and Light” communities have been specified in the following documents: The Constitution, the Card and the Statue. The Constitution of „Faith and Light” specifies organizational rules operating at local, provincial and international levels. The Card of „Faith and Light” describes in great detail the tasks of the community. The Statue explains the aims and formal conditions of functioning in the community.

Every meeting of the community is divided into 3 „stages”: 1) prayer, 2) celebration, 3) sharing experiences and considerations. Sometimes meetings of people with disabilities with friends at their homes or outside them to integrate, pray and play are called „the fourth one”.
Friend - an expression used by Jean Vanier regarding caretakers/ volunteers of disabled people to emphasize the value of every person and the social and partner relations between members of „Faith and Light" movements and in "L'Arche” Homes. 


\section{Formacja modlitewna, jako element integral- nego rozwoju człowieka w Ruchu „Wiara i Swia- tło"}

Założyciele „Wiary i Światła” wskazali formację modlitewną jako niezbędny czynnik rozwoju osoby z niepełnosprawnością i jej najbliższego otoczenia. W związku z tym, myśląc o modlitwie jako o swoistym narzędziu wzrastania i wychowania człowieka, należy mieć na uwadze prawidłowości ludzkiego rozwoju. W pedagogice i psychologii rozwoju istnieją liczne propozycje, prezentujące periodyzację życia człowieka, wyjaśniające jego złożoność. Na gruncie pedagogiki - nauki o wychowaniu, rozumianym jako wspomaganie rozwoju człowieka powstała m.in. teoria warstwicowa, zmierzająca do ukazania wszystkich, zróżnicowanych, możliwości rozwoju osoby. Teoria ta zapoczatkowana została przez Wilhelma Flitnera. Ten niemiecki pedagog założył istnienie 4 linii rozwoju człowieka: 1) naturalny wzrost, 2) społeczne przekazywanie kultury, 3) rozwój wartości, 4) rozwój duchowy, prowadzący do życia moralno-religijnego. Sergiusz Hessen pogłębił teorię warstwicową, wskazując na to, że osoba istnieje w czterech płaszczyznach bytu. $\mathrm{Na}$ ich podstawie wyodrębnił następujące warstwy wychowania: psychofizyczną, społeczną, kulturalną i moralną (w niej jednostka ludzka funkcjonuje „jako członek królestwa duchów”) (Hessen, 1939, s. 215-241). Teoria warstwicowa zakłada, że wszystkie warstwy rozwijają się w człowieku „we właściwym dla siebie czasie i ustalonej kolejności", tym samym „tworząc różne podłoża wychowania” (Kunowski, 1993, s.195). Odnosząc się do założeń teorii warstwicowej Hessena Stefan Kunowski wyróżnił pięć okresów rozwojowych, przebiegających w granicach siedmioleci, które są swoistym kryterium w ocenie tempa rozwoju człowieka. Dla tych okresów rozwojowych podstawę stanowi pięć warstwic wychowania: 1) biologiczna, 2) psychologiczna, 3) socjologiczna, 4) kulturologiczna, 5) duchowa lub światopoglądowa. Kunowski podkreślał, iż rozwój ostatniej warstwy - duchowej - powoduje, że wychowanek uczy się wartościowania i dążenia do ideału Prawdy, Dobra i Piękna. Stwierdzał, że rozwój duchowości kształtuje wolność wyboru drogi życiowej, odpowiedzialność za własne postępowanie, budzi refleksje egzystencjalne i prowadzi do modelowania własnego światopoglądu. Efektem końcowym rozwoju tej warstwy jest ukształtowanie przekonań religijno-moralnych, rozwiązanych teistycznie lub ateistyczne. Niezależnie od typu ukształtowanego światopoglądu, jego rozwój odbywa się poprzez głębokie przeżycie, wynikające z czci odnoszącej się do Absolutu. Źródła bytu, rozumiane jako „odwieczna materia” lub jako duch, filozoficznie zostają deifikowane czyli ubóstwione. Dlatego przeżycia światopoglądowe mają charakter religijny i modlitewny. Modlitwa według Stefana Kunowskiego „[...]tworzy rozwojową formę życiową w warstwie czysto duchowej" (Kunowski, 1993,

\section{A prayer formation as an integral element of person's development in "Faith and Light" Movement}

The founders of "Faith and Light" indicated a prayer formation as an essential element of development of disabled people and their families. In this regard, when we see a prayer as a tool helping a person grow and raise, we have to keep in minds a pattern of human development. In both pedagogy and psychology of human development there are numerous suggestions, presenting periodicity of human life, explaining its complexity. On the basis of pedagogy - the study of upbringing, understood as supporting human developmentgave rise to a theory XXXXXX that aims at showing all diversified options of human development. This theory was initiated by Wilhems Flitner. This German pedagogue assumed the existence of 4 lines of human development: 1) natural growth, 2) socially passed down norms, 3) development of values, 4) spiritual development that leads to morally religious life. Sergiusz Hessen deepened the theory of contour lines, pointing out to the fact that a person lives on four levels of existence. On their basis he distinguished the following layers of upbringing: psycho-physical, social, cultural and moral (in which an individual functions "as a member of the kingdom of spirits") (Hessen, 1939, p.215-241). The theory of contour lines assumes that all the layers develop in a human "at the right time and in a set order", at the same time "creating different bases of upbringing" (Kunowski, 1993, p.195). In relation to the assumption of XXX Hessen's theory, Stefan Kunowski distinguished five development periods, each of them taking place within a period of seven years, which are kind of a criterium in evaluating the development rate of a human. The base for these development periods are five contour lines: 1)biological, 2) psychological, 3) sociological, 4) culturological, 5) spiritual or connected with worldview. Kunowski pointed out that the development of the last layer - the spiritual one - teaches a pupil to strive for excellence Truth, Goodness and Beauty. He claimed that the spiritual development shapes the freedom of choice of a life path, responsibility for one's own choices, which makes us wonder about our existence and leads to modelling our own worldview. The final effect of the development of this layer is forming the religious and moral beliefs, that are solved in a theistic or atheistic way. Regardless of the type of formed worldview, its development takes place through a deep experience, stemming from the worship of the Absolut. The sources of life that are understood as "the ethereal matter" or as a spirit, are unedified worshipped. Which is why the experience regarding the worldview is of religious and prayerful character. A prayer, according to Stefan Kunowski "[...] creates a developing form of life in a purely spiritual layer" (Kunowski, 1993, p.213). The goal of this prayer 
s.213). Zadaniem tej modlitwy - kontemplacji jest wydobywać z osoby ludzkiej i rozwijać pełnię jej człowieczeństwa.

Rozwój warstwy duchowej we Wspólnocie „Wiara i Światło" jest realizowany - z założenia - przez wspólne bycie z innymi, słuchanie słowa Bożego, modlitwę i przyjęcie sakramentów. Formacja modlitewna jest tu podstawą do wzrostu ku dojrzałości duchowej, kształtowania postaw moralnych oraz wychowania do życia we wspólnocie. Jej założenia i realizacja we Wspólnotach „Wiara i Swiatło” wskazują na istotne właściwości formacji modlitewnej, wypracowane w Kościele katolickim, stąd obowiązujące w nim dokumenty wyjaśniają wiele, jeśli chodzi o zasady jej prowadzenia.

W świetle tych uregulowań (np. Dyrektorium Ogólnego o Katechizacji) aktom modlitwy w toku formacji modlitewnej przewodniczy katecheta ${ }^{3}$, który może być zarówno osobą posiadającą specjalne święcenia osoby duchownej jak też osobą świecką. Rolę katechety we Wspólnotach „Wiara i Światło”, z założenia, przyjmują Przyjaciele.

Dyrektorium Ogólne o Katechizacji (1998) wskazuje na konkretne wymagania, które są stawiane katechetom i powinny dynamizować ich formację jako taką, nie tylko modlitewną, na co dzień. Formacja ta składa się z trzech elementów: 1) „być”, 2) „wiedzieć”, 3) „umieć działać”[155-156]. Formacja na poziomie "być” odnosi się do osoby katechety - cała jego aktywność, w tym modlitwa, ma pomóc w jego rozwoju duchowym i indywidualnym, w osiąganiu duchowej dojrzałości. Formacja na poziomie „wiedzieć” oznacza, że katecheta musi być świadomy tego, co przekazuje innym (tu: poprzez modlitwę), komu i w jakim kontekście społecznym. W wymiarze „umieć działać” formacja katechety owocuje umiejętną komunikacją z innymi (również poprzez modlitwę), działaniami świadczącymi o jego pedagogicznych i psychologicznych kompetencjach. Dyrektorium wymaga od katechety swojego rodzaju elastyczności podczas przekazywania chrześcijańskiego nauczania. Ważne jest przy tym, aby katecheta łączył rolę nauczyciela, wychowawcy i świadka. Rola nauczyciela sprowadza się do nauczania wiary przez przekazywanie wiadomości „teoretycznych”, jak również osobistych przeżyć i doświadczeń modlitwy. W podejmowanych aktach wychowania do modlitwy najważniejszym zadaniem katechety jest wzbudzenie potrzeby rozwoju modlitewnego wychowanków i pomoc im w nawiązaniu lepszego dialogu z Bogiem (Dyrda, 2008). Trzecia rola katechety jest „bycie świadkiem”, czyli dawanie świadectwa o prawdach chrześcijańskich w oparciu o własne, głębokie przeżywanie wiary (Dyrda, 2008).

\footnotetext{
${ }^{3}$ Według Encyklopedii katolickiej, katecheta - to urzędowy świadek wiary Kościoła (duchowny lub świecki), który uczestniczy w głoszeniu Ewangelii poprzez zaangażowanie w katechizację na podstawie odpowiedniego przygotowania. W wąskim znaczeniu katecheta to nauczyciel zajmujący sie nauczaniem religii, w szerszym - każda osoba wierząca, przekazująca prawdy wiary i zasady moralne.
}

- contemplation is extracting from a person and developing their full humanity.

The development of the spiritual layer in "Faith and Light" community is by definition realized by being with others, listening to the God's word, prayer and taking sacraments. A prayer formation is here a fundament for growing to spiritual maturity, shaping moral stances and education for life in a community. Its ideas and realization in "Faith and Light" communities indicates crucial prayer formation characteristics, worked out in Catholic Church, hence the applicable in it documents explain a lot, when it comes to the rules of leading it.

In light of these regulations (i.e. General Directory of Catechization) the catechist ${ }^{3}$ leads the acts of prayer in a prayer formation, who could either have special empowerments of a clergyman or be a layman. The role of catechist in "Faith and Light" communities is usually taken over by Friends.

General Directory of Catechization (1998) points out at specific requirements that are demanded from catechists and should dynamize the formation as a whole, every day. This formations consist of three elements: 1)"to be", 2)"to know", 3)"to be able to act" [155-156]. The "to be" formation relates to a catechist - his whole activity, including prayers, is supposed to help in his spiritual and individual development, in reaching the spiritual maturity. The "to know" formation means that a catechist has to be aware of what he communicates to others (here: by prayer), whom and in that social context. In the sense of "to be able to act" the catechist formation results in the ability to communicate with others (also through a prayer), the actions proving this pedagogical and psychological competences. Directory demands from the catechist a certain flexibility while he or she is teaching. It is important that the catechist combines a role of a teacher, a counsellor and a witness. The role of a teacher comes down to teaching about faith by passing the "theoretical" information, as well as personal experiences and prayers. In undertaken acts of education in terms of prayer the most important task of catechist is to awaken the need for development in pupils when it comes to praying and helping them to connect with God better. (Dyrda, 2008). The third role is "being a witness", thus giving a testimony of Christian truths on the basis of own, deep experiencing of faith. (Dyrda, 2008).

In the functioning of "Faith and Light" communities, these three above mentioned dimensions are clear. The "to be" dimension is by principle the base of every Community's meeting. Jean Vanier, on the basis of his own experiences, said that "Faith and Light" is not about doing something for other people - thus about generosity -but rather

\footnotetext{
According to the Catholic Encyclopedia, catechetic- an administrative Church's witness of faith (cleric or secular), that participates in preaching of the Gospel by being involved in catechization on bases of adequate preparation. In a narrow sense, catechetic is a teacher that teaches religion, in a broader sense- every religious person, passing the truths of faith and moral rules to others.
} 
W działalności wspólnot „Wiara i Światło”, bardzo wyraźnie w ich formacji modlitewnej, odnaleźć można trzy wspomniane wyżej wymiary. Wymiar „być” jest - z założenia - podstawą każdego spotkania Wspólnoty. Jean Vanier, w oparciu o swoje doświadczenie powiedział, że „w Wierze i Świetle nie chodzi przede wszystkim o to, by robić coś dla ludzi - o hojność - ale o to, by być obecnym. Chodzi o sposób słuchania drugiej osoby, o jej przyjęcie, o spojrzenie, o wzajemną obecność". Obecność, werbalne i niewerbalne, ale szczere wyrażanie samego siebie, wzajemna pomoc i wsparcie $\mathrm{w}$ dźwiganiu „swoich krzyży”, stają się „wyrazem Bożej miłości” i pomagają w dojrzewaniu osobistym (Karta Wiary i Światła).

Wymiary „wiedzieć” i „umieć działać” w największym stopniu - z założenia - stanowią zobowiązanie dla Przyjaciół. Przyjaciele powinni być w pełni świadomi tego, że każda osoba ludzka, niezależnie od stopnia niepełnosprawności, ma takie same prawa do bycia akceptowaną, docenianą, „jak również prawo do otrzymania każdej potrzebnej pomocy, by mogła rozwijać się na wszystkich poziomach, zarówno w wymiarze naturalnym, jak i duchowym" (Karta Wiary i Światła). Ich zadaniem jest nauczyć się postrzegać osoby z niepełnosprawnością w świetle Ewangelii, akceptować ich słabości i umieć odpowiadać na ich potrzeby. Wymaga to akceptacji osób z niepełnosprawnością intelektualną oraz przejścia od egoistycznego „wspólnota dla mnie" do pewnego rodzaju altruizmu - „ja dla wspólnoty" (Vanier, 2011, s.81). Zadaniem Przyjaciół jest wspieranie osób z niepełnosprawnością oraz ich bliskich $\mathrm{w}$ nieustannym wchodzeniu na poziom „wiedzieć” i „umieć działać”. Jak pokazuje praktyka Wspólnot, Przyjaciele, osiągając te wymiary, nierzadko uczą się od swoich podopiecznych. Swoistym obszarem tej nauki bywa modlitwa wspólnotowa i owoce całej formacji modlitewnej wszystkich uczestników wspólnot.

Modlitwa bowiem, obok obecności przy drugim człowieku oraz świadomości jedności wspólnotowej - jak chcieli tego twórcy „Wiary i Światła” - stanowi podstawę istnienia tej wspólnoty. Jest ważnym narzędziem umożliwiającym zmierzanie „ku głębszemu pojmowaniu własnej tożsamości” (Vanier, 2011).

Rozwój duchowy w Ruchu „Wiara i Światło” nie ogranicza się tylko do comiesięcznych spotkań wspólnot. Oprócz nich wspólnoty oferują swoim członkom rekolekcje, obozy wakacyjne, pielgrzymki. Prowadzą również współpracę z innymi wspólnotami, zachowując przy tym swoją specyficzną religijność, nie narzucając jej jednak innym. We wszystkich tych przejawach aktywności wyraźnie zaznacza się obecność i realizacja celów formacji modlitewnej.

Jean Vanier w swoich wypowiedziach (m.in. w publikacjach pt. Odkryć nasze człowieczeństwo (2001), Wspólnota miejscem radości i przebaczenia (2011)), niejednokrotnie podkreśla, że obecność about being present. It is about the way we listen to the other person, about their reception, their look and mutual presence". Presence, verbal and nonverbal, honest expression of oneself, mutual help and support in bearing "our crosses" become a "sign of God's love" and help in personal maturing (The Card of Faith and Light).

The dimensions of " knowing" and "being able to act" are by principle, to the greatest extend possible, an obligation for Friends. Friends should be fully aware that every person, regardless of their level of disability has the same rights to be accepted, appreciated, " as well as the right to get any needed help, so that they could develop on all the levels, in natural and spiritual dimension (The Card of Faith and Light). Their task is to learn how to see the disabled people through the prism of the Gospel, accepting their weaknesses and being able to respond to their needs. It requires accepting intellectually disabled people and going from selfish "the community for me" to the sort of altruistic "me for the community" (Vanier, 2011, p.81). Friend's task is to support the disabled people and their relatives in attempts to get to the "to know" and "to be able to act" levels, that never end. The activity of communities shows that Friends, reaching this levels, often learn from their proteges. A special area of this study is a group prayer and the fruit of the whole prayer formation.

A prayer constitutes, right next to our presence for other people and the awareness of the sense of community, according to the intentions of the founders of "Faith and Light" a base for its existence. It is an important tool enabling heading "towards deeper understanding of one's own identity" (Vanier, 2011).

Spiritual development in "Faith and Light" movement is not limited to monthly meetings. Besides that, the communities offer to their members retreats, summer camps, pilgrimages. They also cooperate with other communities, keeping their unique religiousness, without forcing it onto others. In all of these activities the existence of realization of prayer formation's aims is predominant.

In his statements (i.e. in publications Odkryć nasze człowieczeństwo (2001), Wspólnota miejscem radości i przebaczenia (2011)), (To find our humanity) (2001), (The community as a place of joy and forgiveness) (2011)) Jean Vanier repeatedly points out that the presence of intellectually disabled people in his life helped him find a sense of being a human. By sharing his life with weaker, Vanier discovered that they are a certain expression of the essence of humanity - tenderness and the strength of a human. In a sense, people with disabilities became and are still becoming Vanier's tutors - they allow him to discover the sense of human existence over and over again. The founder of "Faith and Light" convinces that the disabled person is often the subject that a healthy person can learn a lot from. Jean Vanier points out that the 
w jego życiu osób z niepełnosprawnością intelektualną pomogła mu odkryć sens bycia człowiekiem. Przez doświadczenie wspólnego życia z osobami słabszymi Vanier odkrył, że są one wyrazicielami istoty człowieczeństwa - kruchości i siły człowieka. Osoby z niepełnosprawnością w pewnym sensie stały i nieustannie stają się dla Vaniera wychowawcami - na nowo odkrywają dla niego sens ludzkiej egzystencji. Twórca „Wiary i Światła” przekonuje, że osoba $\mathrm{z}$ niepełnosprawnością jest bardzo często tym podmiotem, od którego człowiek pełnosprawny może się nauczyć bardzo wiele. Jean Vanier podkreśla, że spotkania Wspólnoty to dla niego czas wzajemnego ubogacania się, chwile, kiedy „uświadamiamy sobie, że tworzymy jedno ciało, że do siebie przynależymy, że Bóg powołał nas do wspólnoty, abyśmy stawali się źródłem życia dla siebie nawzajem” (Vanier, 2011, s.230). Vanier uwypukla również to, że „wspólnota może się stać miejscem celebracji życia, miejscem, w którym każdy może dzielić z innymi tak cierpieniem, jak i radością, w którym każdy staje się źródłem życia dla innych i w którym każdy odkrywa swoje powołanie i tożsamość jedynie wówczas, gdy więzi uczuciowe nie są zniewalające, lecz przeciwnie, prowadzą do autentycznej wolności" (Vanier, 2011, s.161). Zmierzając do bardziej bezpośredniego dotknięcia kwestii formacji modlitewnej we wspólnotach "L'Arche” oraz „Wiary i Światła”, ich założyciel podkreśla znaczącą rolę asystentów i Przyjaciół w procesie rozwoju duchowego osób z niepełnosprawnością. Ich zadaniem jest głoszenie Dobrej Nowiny oraz „objawienie im [osobom z niepełnosprawnością] siły miłości, jaką Bóg dla nich żywi”. Etap na którym osoby z niepełnosprawnością zaczynają „żyć wiarą" staje się nowym etapem wiary dla osób im towarzyszących. W ten sposób osoby $\mathrm{z}$ niepełnosprawnością stają się nauczycielami, wychowawcami, świadkami, wspomagającymi rozwój duchowy osób ich otaczających (Vanier, 2011, s.132).

Ukoronowanie formacji modlitewnej członków „Wiary i Światła” widział Vanier w ich osobistym spotkaniu z Bogiem podczas Eucharystii oraz w postawie ich „wierności siostrom i braciom” ze wspólnoty, w tym też w trwaniu we wspólnej modlitwie (Vanier, 2011, s.134-138). To w aktach modlitwy osoby z niepełnosprawnością są przykładem prostoty i szczerości, bezpośredniości i umiejętności słuchania. Osoby te, określane przez społeczeństwo jako nie w pełni sprawne, odkrywają przed pełnosprawnymi świat w którym rywalizacja, sytuacja finansowa i sukces zastępowane są wiernością, relacjami przyjacielskimi, radością i wiarą. Przez swoje zachowania niejako próbują wyzwalać w innych gotowość do pełnienia posługi, same zresztą również służąc innym swoja pomocą. Vanier tę gotowość nazywa „darem który jedna osoba może przekazywać drugiej, niczym ogień miłości dający życie wspólnocie" (Vanier, 2011,s. 349). meetings of the Community are for him the time of mutual enrichment, moments when you realize that we constitute one organism, that we co-exist, that God appointed us to this community, so that we can become a source of life for each other" (Vanier, 2011, p.230). Vanier also emphasize that "the community can become a place of celebration of life, the place when everyone can share both suffering and joy, in which everyone becomes a source of life for others and in which everyone discovers their calling and identity only when the emotional bonds are not captivating, quite the opposite - they lead to an authentic freedom" (Vanier, 2011, p.161). Getting closer to facing the issue of prayer formation in "L'Arche" and "Faith and Light" communities more directly, their founder emphasizes a significant role of assistants and Friends in the process of spiritual development of a disabled person. Their task is to preach the Good Tidings and "show them [disabled people] the power of love, which the God feeds them". The phase, when people with disabilities start to "live by faith" becomes a new stage of faith for people that accompany them. In this way the disabled become teachers, counsellors, witnesses, supporting the spiritual development of people that surround them (Vanier, 2011, p.132).

Vanier saw the coronation of prayer formation's "Faith and Light" members in their private meeting with God during the Eucharist and in their attitude of "Faithfulness to sisters and brothers" from the community, including praying together (Vanier, 2011, pp.134-138). The acts of prayer of people with disabilities are some examples of simplicity and honesty, directness and the ability to listen. These people, defined by the society as not fully capable of doing things, reveal to the healthy people the world where rivalry, financial situation and success are replaced by faithfulness, friendliness, joy and faith. By their actions they try to awaken in others the readiness to serve God, while also being ready to help others. Vanier calls this readiness "a gift that one person can give to another as if it was fire giving life to the community" (Vanier, 2011, p.349). 


\section{Formacja modlitewna w świetle własnych ba- dań empirycznych}

$\mathrm{Na}$ użytek poruszanej w tym artykule problematyki przeprowadzono badania ankietowe, których celem było uzyskanie odpowiedzi na pytanie o znaczenie, jakie nadaja formacji modlitewnej we wspólnotach „Wiary i Swiatła” osoby sprawujące funkcję opiekunów osób $\mathrm{z}$ niepełnosprawnością intelektualną. Zastosowanym narzędziem badawczym był składający się z 10 pytań kwestionariusz ankiety. Badania zostały zrealizowane 5 maja 2018 roku, podczas pielgrzymki rodzin z dziećmi z niepełnosprawnością oraz osób, które wyraziły chęć towarzyszenia im w dniu świętowania 40. rocznicy istnienia Ruchu w Polsce. W związku z obchodami tej rocznicy wszystkie Wspólnoty „Wiara i Światło” z Polski miały możliwość uczestniczyć w uroczystościach w Kalwarii Zebrzydowskiej.

W badaniu wzięli udział Przyjaciele (w tym też rodzice oraz kapelani) z 12 Wspólnot z różnych części Polski (Bielsko-Biała, Bydgoszcz, Czarny Dunajec, Lublin, Łańcut, Olsztyn, Poznań, Trzebina, Warszawa, Więcbork, Wrocław). Łączna liczba badanych wyniosła 31 osób. Do badań przystąpiło 21 kobiet i 10 mężczyzn w wieku od 17 do 72 roku życia. Badanych posiadających wyższe wykształcenie było 18 , średnie - 10 , zawodowe - 1 oraz podstawowe -2 osoby.

Głównym celem badań było ustalenie znaczenia, jakie nadają formacji modlitewnej we Wspólnotach „Wiara i Światło” osoby, które wyraziły chęć pogłębienia więzi z osobami z niepełnosprawnością oraz ich rodzicami, w tym kapelani.

W odpowiedzi na pytanie o to, czym jest dla nich modlitwa, 29 z 31 osób udzieliło podobnej odpowiedzi. W większości Przyjaciele definiowali modlitwę, jako „osobistą rozmowę - spotkanie z Bogiem”, „dziękczynienie, uwielbienie, prośbę lub przebłaganie”. Jedna z badanych osób określiła modlitwę „jako sens życia”, a inna jako „ukojenie, przy natłoku myśli, zadumę”. Uzyskane wyniki świadczą o wysokim poziomie świadomości istoty i znaczenia modlitwy badanych, potwierdzającym ich osobistą pracę nad tym elementem życia duchowego. Potwierdzają, iż badani traktują modlitwę jako żywą relację z drugą osobą.

W odpowiedzi na pytanie o to, kto inspiruje ich do modlitwy, ponad połowa badanych (16 osób) wskazała: wspólnotę, przyjaciół z „Wiary i Światła”, osoby z niepełnosprawnością intelektualną. Ankietowani podkreślali przy tym spontaniczność, prostotę i szczerość osób z niepełnosprawnością intelektualną. 11 z 31 badanych wskazało tu rodziców/ rodzinę. Wzorem do naśladowania w modlitwie dla 11 osób - w świetle ich deklaracji - jest ksiądz (kierownik duchowy, kapelan wspólnoty). 3 badanych zadeklarowało, że poszukując inspiracji do modlitwy, korzysta z Internetu i literatury na ten temat. Jedna osoba zadeklarowała, że przykładu modlitwy dostarczają jej Przyjaciele. Również jed-

\section{A prayer formation in the light of personal empirical studies}

For the use of the issues discussed in this article, surveys were conducted, and their aim was to get an answer to the question of the meaning that people taking care of intellectually disabled ones assign to formations. The used analytical tool was a questionnaire consisting of 10 questions. The study was realized on the 5th May 2018 during the pilgrimage of families with children with disabilities and people that wanted to accompany them on the day of Polish Movement's 40th Anniversary. In connection to celebrating of this anniversary, all "Faith and Light" Communities from Poland had an opportunity to participate in celebrations in Caldaria Zebrzydowska.

Friends (as well as parents and chaplains) from 12 Communities from different parts of Poland (Bielsko-Biała, Bydgoszcz, Czarny Dunajec, Lublin, Łańcut, Olsztyn, Poznań, Trzebina, Warszawa, Więcbork, Wrocław) took part in the study. A total number of participants was 31.The study was attended by 21 women and 10 men at the age from 17 to 72.18 of the followers had higher education, 10 - secondary education, 1 - vocational education, 1 - primary education.

The main aim of the study was to determine the meaning that people that expressed their interest in deepening their bond with the disabled people, their parents and chaplains assigned to prayer formations.

In response to the question about the meaning of prayer to them, 29 out of 31 people gave a similar answer. Most of Friends defined prayer as " a personal conversation- a meeting with God", "thanksgiving, praising, request or begging". One of the examined people defined prayer "as a sense of life", another one as "soothing when there are too many thoughts, contemplation". The obtained results indicate a high level of the awareness of being and the meaning of prayer for the participants, confirming their personal work over this element of their spiritual life. They confirm that the examined people treat prayer as a lively relation with another person.

In response to the question, who inspires them to pray, over half of the respondents (16 people) noted: the community, friends from "Faith and Light", intellectually disabled people. The participants emphasized the spontaneity, simplicity and honesty of people with intellectual disability. 11 out of 31 indicated people named their parents/family. The role model to follow in prayer for 11 people - according to their declarations - was a priest (a spiritual director, chaplain of the community). 2 participants declared that when looking for an inspiration to pray they use the internet and the subject literature in this regard. One person declared that Friends are an example of prayer for him. Another person said that all the saints are 
na osoba wskazała, że takim przykładem są dla niej święci. Zebrane wyniki badań świadczą o dążeniu członków wspólnot do rozwoju duchowego przede wszystkim poprzez naśladowanie pozytywnych wzorów zachowań dostarczanych im przez osoby duchowne lub świeckie, które przewodniczą wspólnocie.

W opinii wszystkich badanych modlitwa w ich życiu odgrywa ważną rolę. Dla 8 osób modlitwa jest fundamentem, stałym elementem ich życia codziennego. Pośród przymiotów modlitwy, które zasługują na szczególną uwagę, badani wymieniali: „nadzieję” (20 osób), „poszukiwanie kierunku działania” (16 osób), „możliwość wyciszenia się i odpoczynku” (11 osób), „możliwość wyrażenia wdzięczności, prośby” (10 osób). Zebrane dane wskazują, że modlitwa jest jednym z podstawowych elementów życia duchowego, które pozwalają na medytację, kontemplację rzeczywistości i dialog wewnętrzny.

Jedno z pytań ankietowych dotyczyło roli modlitwy w działalności wspólnot „Wiary i Światła”. Odpowiedzi badanych podzieliły się tu na dwie kategorie. Część ankietowanych wyjaśniła znaczenie modlitwy w działalności badanych wspólnot jedynie $\mathrm{z}$ perspektywy indywidualnego rozwoju duchowego np.: „uczy [mnie] rozmowy z Bogiem”, „jest miejscem bliższego poznawania Boga, umocnieniem wiary”, „daje radość i spokój wewnętrzny”, „pomaga zrozumieć znaczenie życia i choroby, odnalezienie sensu życia”. Część osób określiła rolę modlitwy w działalności wspólnot „Wiara i Światło”, wyróżniając jej walory wspólnotowe: „poczucie miłości i radość z tego, że mogę pomagać”, „daje poczucie wspólnoty”; „pokazuje sens i radość z troski o innych”; „modlitwa wspólnotowa daje doświadczenie spontanicznej miłości”, „służy wsparciem i natchnieniem do czynnego uczestnictwa w życiu wspólnoty”. Większość ankietowanych (22 osoby) podkreślało, że „modlitwa sprzyja ich samowychowaniu”. Modlitwa nie jest dla nich zatem wyłącznie środkiem osobistego kontaktu z Bogiem, ale posiada przy tym moc autoformacyjną, wzmacniając jednocześnie wspólnotę poprzez zbliżanie jej członków, zacieśnianie wzajemnych relacji.

Na pytanie o rolę modlitwy wspólnotowej w życiu osób z niepełnosprawnością wszyscy respondenci odpowiedzieli, że jest ona ważnym czynnikiem ich rozwoju i jako taka stanowi również ważny element wspólnych spotkań. Jako właściwości wspólnotowej modlitwy, dynamizujące rozwój osób z niepełnosprawnością, ankietowani wymieniali najczęściej: „możliwość wyrażenia siebie, spotkania osobistego z Bogiem”, „wzmocnienie duchowe”, „poczucie wspólnoty, miłości, radości, jedności i bezpieczeństwa, akceptacji”, „poczucie, że [osoby niepełnosprawne] są kochane”, „siłę i odporność na brak tolerancji, [które] utrwalają ich [członków „Wiary i Światła”] wspólne i silne więzi”; „dostrzeganie dobra i wsparcia”. Analiza odpowiedzi wskazuje na to, że w opinii badanych modlitwa objawia swoją moc psychologiczną, łącząc uczestników a collective role model for him. The gathered results indicate the striving of community members to spiritual development, for most of them, by copying positive models of behaviours provided to them by a clergymen or a laic that lead the community.

In everyone's opinion prayer plays a significant role in their lives. For 8 people prayer is a fundament, a permanent element of their everyday life. Among the qualities of prayer that deserve special attention they named: "hope" (20 people), "looking for a direction in their actions" (16 people), "an opportunity to calm down and relax" (11 people), "an opportunity to express gratitude, requests" (10 people). Gathered data indicate that prayer is one of the fundamental elements of spiritual life that enables meditation, contemplation of the reality and inner dialog.

One of the questions regarded the role of prayer in the functioning of "Faith and Light" communities. The answers given by participants may be divided into two categories. Part of interviewees explained the meaning of prayer in functioning of examined communities only from the perspective of individual, spiritual development i.e. "it teaches me how to conversate with God", "it is a place of getting to know God better, strengthening my faith", "it gives me happiness and inner peace", "it helps me to understand the meaning of life and illness, to find the sense of life". Some people emphasized the role of prayer in the functioning of "Faith and Light" communities, distinguishing the qualities of the community: "the feeling of love and joy that I can help", "gives the feeling of community", "shows the sense and joy of taking care of others"; "prayer in a group gives an experience of spontaneous love", "it provides me with support and inspiration to actively participate in the life of the community". Most of the interviewees (22 people) emphasized that "prayer supports their self-education" Prayer is then not only a way of contacting with God, but also has an auto formational power, at the same time strengthening the community by bringing their members together, helping them bond with each other.

When answering the question about the role of praying in communities in life of the disabled people all interviewees said that it was an important factor of development and that it formed an important element of the meetings. As a feature of praying in communities, dynamizing the development of disabled people, interviewees usually named: "an opportunity to express oneself, a personal meeting with God", " spiritual strengthening", "a feeling of being in a community, love, joy, unity, safety, acceptance", "a feeling that they [disabled people] are loved", "strength and resistance to lack of tolerance, that perpetuates their [the members of "Faith and Light"] strong bonds ", "noticing the good and support:. The analysis of the answers indicates that in the interviewees' opinion prayer shows its deep psychological power, bringing members of the 
wspólnoty - pogłębiając więź emocjonalną pomiędzy nimi.

Odpowiadając na pytanie, dotyczace znaczenia modlitwy we Wspólnocie „Wiara i Światło” dla rodziców, respondenci stwierdzali: „modlitwa jest wsparciem w trudnych sytuacjach życiowych", „daje ulgę, radość, wzbogaca rozwój duchowy”, „pomaga w dojrzewaniu, odnajdywaniu sił i sensu"; „pokazuje sens cierpienia i pomaga znosić trudy codziennego życia”; „daje poczucie, że [rodzice] nie są sami”; „pomaga w pogodzeniu się z sytuacją, która ich spotkała, w akceptowaniu niepełnosprawności dziecka". Powyższe wypowiedzi wskazują wyraźnie na to, że badani dostrzegają terapeutyczne znaczenie modlitwy dla rodziców osób z niepełnosprawnością. Rodzice doświadczają bowiem często niezrozumienia i nieakceptacji ze strony niektórych członków społeczeństwa. Wchodząc we wspólnocie w relacyjny wymiar modlitwy, a w nim w odniesienia do kochającego Boga, mogą przeżywać pełną akceptację inności swoich dzieci.

W kwestionariuszu ankiety umieszczono również pytanie o znaczenie modlitwy we wspólnocie „Wiara i Światło" dla uczestniczącego w życiu tej wspólnoty księdza. Większość (17 osób) ankietowanych podziela zdanie, iż doświadczenie modlitwy we wspólnocie pozwala kapłanowi na nowo okryć swoje powołanie (lub umacnia go w tym powołaniu) przez doświadczenie, jakim jest kontakt z osobą z niepełnosprawnością intelektualną. Oto przykładowe odpowiedzi, uznające znaczącą rolę uczestnictwa kapłana $\mathrm{w}$ formacji modlitewnej „Wiary i Światła”: „[modlitwa w „Wierze i Świetle”] ma bardzo duże znaczenie dla księdza - przez modlitwę i kontakt z osobą upośledzoną księża są bliżej Boga”, „[modlitwa we wspólnocie] staje się [dla księdza] źródłem siły, inspiracją do jego rozwoju duchowego", „[we wspólnocie ksiądz] może pokazać inną modlitwę niż te wyuczone, na przykład, scenki czy pantomimę”, „[modlitwa wspólnotowa] jest nowym doświadczeniem [dla księdza], modlitwa „Muminków”4 we wspólnocie jest szczera i autentyczna”. Z analizowanych wypowiedzi wynika, że badani podkreślali przede wszystkim rolę autentyzmu i szczerości osób z niepełnosprawnością podczas modlitwy wspólnotowej, w budowaniu doświadczenia życiowego kapłana. Akcentowali także wyjątkowość spotkania kapłana z osobami z niepełnosprawnością intelektualną.

$\mathrm{W}$ odniesieniu do wypracowanego $\mathrm{w}$ „Wierze i Świetle" sposobu organizowania spotkań wspólnotowych, w ankiecie zostało umieszczone pytanie o rolę poszczególnych „czasów” w procesie kształtowania się doświadczenia modlitwy. Na podstawie udzielonych odpowiedzi można ustalić, że „czas dzielenia” w opinii ankietowanych jest: „czasem przełamywania się, otwarcia serca, które ma prowadzić do przemiany”, „daje możliwość dzielenia

${ }^{4}$ "Muminkami” w Polsce nazywano osoby z niepełnosprawnością intelektualną, nazwa pochodzi od tytułu skandynawskich książek Tove Jansson, których bohaterowie tworzyli kochającą się rodzinę. community together by deepening the emotional bond between them.

In order to answer the question about the meaning of prayer for the parents in "Faith and Light" movement, the interviewees stated: "prayer is a support during hard times", "it gives relief, joy, enriches my spiritual development", "helps me in maturing, find strength and sense"; "shows the sense in suffering and helps to deal with everyday hardships"; "gives the feeling that they [parents] are not alone" ; "helps to deal with a situation that happened to them, in accepting their child's disability". All of the above answers clearly indicate that the interviewees can see the therapeutic significance of prayer for parents that have a disabled child. The parents often experience lack of understanding and acceptance from other members of the society. By entering into the dimension of prayer in the community and by references to the loving God, they can experience a full acceptation of their children's "otherness".

In the questionnaire there was also a question about the meaning of prayer in the "Faith and Light" community for the priest participating in the life of this community. Most of the interviewees (17 persons) shared a viewpoint that experiencing prayer in the community enables the priest to reexperience his calling (or makes it stronger) by the experience of contact with an intellectually disabled person. Some of the answers, that recognize a significant role of priest' participation in "Faith and Light's" prayer formation: "[prayer in "Faith and Light" has a lot of meaning for the priest - by prayer and contact with a disabled person priest gets closer to God", "it [prayer in the community] becomes for him [ the priest] a source of power, inspiration to his spiritual development", "he [in the communities a priest] can show a different kind of prayer than the ones learned by heart, for example, sketches and pantomime", "it [prayer in the community] is a new experience [for the priest], a prayer of "Moomins"4 in the community is honest and authentic". From the analysed answers it appears that the interviewees emphasized the role of authenticity an honesty of disabled people during prayers in the community, in gaining priest's life experience. They also stressed the exclusiveness of priest's meeting with intellectually disabled people.

In connection to the way of organizing the meetings in "Faith and Light", there was a question in the survey about the role of each of the "times" in the process of forming the experience of prayer. Based on the given answers we can establish that "the time of sharing" is, in interviewees' opinion, sometimes "a time of breaking the barriers, opening hearts, that is supposed to lead to the transformation", "that gives the possibility to share reflections and experiencing prayer", "shows

${ }^{4}$ In Poland, people with intellectual disabilities were often called "Moomins"; this name comes from the Scandinavian book series, whose characters created a loving family. 
się refleksjami oraz doświadczeniem modlitwy", „pokazuje ten sam problem oczami innych”, „uczy, że obecność przy drugiej osobie jest ważniejsza od tego, co się posiada”, „pozwala dogłębnie zrozumieć słowo Boże, wyrazić swoje zdanie, podzielić się swoim doświadczeniem, ale i czerpać z wiedzy innych”, „daje możliwość zrozumienia Ewangelii w prosty sposób".

Z kolei „czas modlitwy” „daje możliwość otwarcia się, (...)bez wstydu i z poczuciem pełnej akceptacji”, „,jest siłą wspólnoty”, „pomaga odnaleźć swój, najbardziej skuteczny sposób modlitwy”, „modlitwa jednoczy wokół Jezusa”, ,jest centralnym punktem spotkań wspólnoty".

Odpowiedzi na powyższe pytanie, dotyczące „czasu świętowania”, skupiły się na podkreśleniu wspólnego „bycia razem”. Można z nich wywnioskować, że samą obecność i działania we wspólnocie ankietowani traktują jako formę modlitwy. Prawdopodobnie jest to wyraz identyfikacji z myślą Jeana Vaniera, że samo „bycie razem” jest formą modlitwy, jest swojego rodzaju „świętowaniem modlitwą”.

Najmniej odpowiedzi udzielono na pytanie dotyczące „czasu wierności” - 10 z 31 osób nie odpowiedziało na tę kwestię w ogóle. Ten fakt pozwala na przypuszczenie, iż we wspólnotach, do których ankietowani przynależą, „czas wierności” nie jest być może znaczącą formą spędzania wspólnego czasu z osobami z niepełnosprawnością oraz ich rodzinami. Bądź też w „czasie wierności” ankietowani nie dostrzegają elementu formacji modlitewnej. Niemniej jednak ci badani, którzy udzielili tu odpowiedzi określają czas poza comiesięcznymi spotkaniami, czasem pozwalającym na "pogłębianie więzi między członkami wspólnoty”, ,[czasem, który] uczy cierpliwości i pokory oraz mobilizuje do modlitwy”, „próbą, dającą szanse wzrostu duchowego”, „[czasem, który] kształtuje modlitwę dziękczynną".

Odpowiedzi badanych na ostatnie pytanie o element integracyjny, wynikający z doświadczenia modlitwy potwierdziły przekonanie respondentów o znaczącej roli modlitwy w integracji członków wspólnoty. Respondenci stwierdzali, że modlitwa jest dla nich „elementem integracyjnym każdego spotkania”, „wprowadza jedność, miłość, pokój i radość”. Modlitwa „pomaga w rozwiązy waniu małych konfliktów, problemów, jeśli się pojawiają” oraz „daje poczucie wspólnoty”, buduje „wiarę w jednego Boga”, rodzi „pełną akceptację dla wypowiadanych próśb, które są wygłaszane bez poczucia wstydu".

\section{Podsumowanie}

Zebrane wyniki badań pozwalają wnioskować, że członkowie „Wiary i Światła” (tu ich wyrazicielami byli tzw. Przyjaciele) nadają formacji modlitewnej wyjątkowe znaczenie w działalności tej wspólnoty. Znaczenie to wiążą nie tylko z rozwojem osób z niepełnosprawnością intelektualną, ale też $\mathrm{z}$ (auto) formacją ich opiekunów, czyli rodziców i Przyjaciół, the same problem thought someone else's eyes", "teaches that standing by the other person is more important than anything that we own", "enables to deeply understand the God's word, express one's opinion, share experiences, but also use the knowledge of others", "gives the opportunity to understand Gospel in a simple way.

On the other hand "time of prayer" "gives an opportunity to open yourself up, (...) without shame and with a feeling of full acceptance", "is a power of the community", "helps to find the kind of prayer that works best for us", "prayer unifies us around Jesus", "is a central point of every meeting in the community".

The answer for the mentioned above questions regarding "the time of celebrating", focused on emphasizing "being together". We can conclude that the sole presence and actions in the community, the interviews treated as a form of prayer. It is probably a token of identification with the thought of Jean Vanier that the sole "being together" is a form of a prayer, a sort of "celebration of a prayer".

The least amount of answers were provided for the question regarding "the time of faith" - 10 out of 31 people did not give any answer. This lets us to assume that in the communities that the interviewees belong to, "the time of faith" is not a significant form of spending time with disabled people and their families. Other option is that they do not see elements of prayer formation in "the time of faith". Either way, the interviewees that did give an answer specified the time besides monthly meetings, sometimes allowing them "to deepen the bond between members of the community", "[sometimes] to teach them patience and submissiveness and motivate to pray", "a request that gives a chance for a spiritual growth", "[sometimes] that gives a form to a prayer of thanksgiving".

The answers granted by the participants to the last question about the integrational element, stemming from the experience of prayer confirmed the interviewees' belief about a significant role of prayer in integrating members of the community. The interviewees stated that prayer is for them 'an integrational element of every meeting", "brings unity, love, peace and joy". A prayer "helps to solve small conflicts and problems, if they occur" and "gives a feeling of community", creates "faith in one God", gives "full acceptation for the requests that are said without feeling any shame".

\section{Summary}

The gathered test results let us assume that the members of "Faith and Light" (in this case the socalled Friends are their articulators) give a special meaning to the functioning of this community. They heavily connect it not only with personal development of people with intellectual disability, but also with (auto)formation of their guardians- 
a także sprawującego nad nimi wszystkimi opiekę duszpasterską kapłana. Modlitwa w opinii badanych respondentów sprzyja rozwojowi duchowemu, wszystkich członków wspólnoty, służy ich samowychowaniu, jest elementem integracyjnym, pogłębia więź emocjonalną pomiędzy uczestnikami działań wspólnotowych. W swoich wypowiedziach badani podkreślali, iż formacja modlitewna przynosi wymierne efekty w odniesieniu do rozwoju wszystkich osób tworzących wspólnotę, konkretyzowali je w swoich wypowiedziach. Dla rodziców - w opinii badanych - modlitwa nabiera przede wszystkim znaczenia terapeutycznego. W przypadku kapłana - sprzyja głównie pogłębieniu jego wrażliwości. Wszystkim członkom wspólnoty - zdaniem respondentów - modlitwa przynosi określone korzyści psychiczne (szczególnie w sferze emocji oraz akceptacji siebie i innych), a także duchowe - związane z intensyfikacją osobistego wysiłku na rzecz szukania odpowiedzi na pytania o sens życia i kształt własnych relacji z Absolutem.

Modlitwa jest doświadczeniem człowieka wyznającego wiarę w Boga. Z tego powodu można mówić o ograniczonym jej oddziaływaniu na opiekunów osób z niepełnosprawnością i same te osoby, jeśli obca jest im wiara religijna. Do wspólnot „Wiary i Światła” należą przede wszystkim ci, którzy deklarują wiarę w Boga (takimi byli badani respondenci). Wspólnoty te jednak nie zamykają się na niewierzących. Dla tych ostatnich doświadczenie modlitwy innych - jej formy i treści, indywidualnego i osobowego charakteru - również może nabrać znaczenia zbliżonego do tego, które jest mu nadawane przez osoby wierzące. parents and Friends and also a chaplain that is in charge of their pastoral care. A prayer, in the interviewees' opinion, contributes to the spiritual development of all the members of the community, assisting with their self-education, constituting an integrating element, deepening the emotional bond between members of the community. In their statements they emphasized that the prayer formation brings measurable benefits in terms of the development of all the people that form part of a given community, which they expressed in detail in their statements. For parents - in the researchers' opinion - prayer receives most of all a therapeutic meaning. In case of a chaplain - it is beneficial by way of deepening his sensitivity. For all the members of the community - in the opinion of the interviewees - prayer has some set psychological benefits (especially in the sphere of emotions and acceptance of oneself and others), but also spiritual ones connected with intensification of a personal efforts aimed at looking for an answer about the sense of life and the shape of one's personal relation with the Absolut.

A prayer is an experience of a religious person. For that reason, we can talk about its limited impact on guardians of the disabled people and the disabled people themselves, provided they are not religious. All those, who declare to believe in God (such as the interviewees) mostly belong to the "Faith and Light" communities. The communities do not close their doors BEFORE non-believers. For them, experiencing other people's prayer - its form and content, individual and personal character - can also obtain a meaning similar to the one that it is perceived by religious people.

\section{Literatura / References}

1. Chlewiński, Z. (1998). Formacja. W: L. Bieńskowski, P. Hemperk, S. Kamiński, J. Misiurka, K. Stawecka, A. Stępień, A. Szafrański, J. Szlaga, A. Weissa (red.), Encyklopedia Katolicka, t.V (389-392). Lublin: Towarzystwo Naukowe KUL.

2. Sobór Watykański II (2002). Deklaracja o wychowaniu chrześcijańskim „Gravissimum educationis”, 28.10.1965. W: Sobór Watykański II, Konstytucje. Dekrety. Deklaracje. (s. 314-324). Poznań: Pallotinum.

3. Dyrda, Z. (2008). Modlitewna formacja katechetów. Tarnów: Wydawnictwo Diecezji Tarnowskiej BIBLOS.

4. Hessen, S. (1993). O sprzeczności i jedności wychowania. Lwów: Książnica - Atlas.

5. Jan Paweł II. (2001). Novo millennino ineunte. Pobrane z: http://www.opoka.org.pl/biblioteka/W/WP/ jan_pawel_ii/listy/novo_millenio_06012001.html.

6. Karta Wiary i Światła. Pobrane z: www.wiaraiswiatlo.pl., [dostęp 30.01.2015]

7. Kasjaniuk, E. (2008). Modlitwa. W: S. Wilk, E. Ziemann, R. Sawa, K. Góźdź, J. Herbut, S. Olszak, R. Popowski (red.), Encyklopedia katolicka, Tom XII, (s. 1539-1545). Lublin: TN KUL.

8. Katechizm Kościoła Katolickiego, (1994), cz. 4, nr 2689. Poznań: Pallotinum.

9. Koczot, J., Kowalczyk, S. [opr.]. (2005). „Nigdy więcej sami! ”Historia Wiary i Światła w Polsce 1978-2014. Kraków: Wydawnictwo Zak.

10. Kongregacja ds. Duchowieństwa (1998). Dyrektorium ogólne o katechizacji. Poznań: Pallottinum.

11. Kunowski, S. (1993). Podstawy współczesnej pedagogiki. Warszawa: Wydawnictwo Salezjańskie.

12. Mathieu, M-H., Vanier, J. (2014). Nigdy więcej sami. Przygoda Wiary i Światła. Kraków: Wydawnictwo Żak.

13. Nowak, M. (1999). Podstawy pedagogiki otwartej. Lublin: Redakcja Wydawnictw KUL.

14. Statut Wiary i Światła. Pobrane z: www.wiaraiswiatlo.pl., [dostęp: 30.01.2015]

15. Vanier, J. (2011). Wspólnota miejscem radości i przebaczenia, Poznań: W drodze 